IZA DP No. 9187

A Bitter Medicine?

Short-term Employment Impact of Deregulation in Network Industries

Andrea Bassanini

July 2015 


\title{
A Bitter Medicine? Short-term Employment Impact of Deregulation in Network Industries
}

\author{
Andrea Bassanini \\ $O E C D$, EconomiX and IZA
}

Discussion Paper No. 9187

July 2015

IZA

\author{
P.O. Box 7240 \\ 53072 Bonn \\ Germany
}

\author{
Phone: +49-228-3894-0 \\ Fax: +49-228-3894-180 \\ E-mail: iza@iza.org
}

\begin{abstract}
Any opinions expressed here are those of the author(s) and not those of IZA. Research published in this series may include views on policy, but the institute itself takes no institutional policy positions. The IZA research network is committed to the IZA Guiding Principles of Research Integrity.

The Institute for the Study of Labor (IZA) in Bonn is a local and virtual international research center and a place of communication between science, politics and business. IZA is an independent nonprofit organization supported by Deutsche Post Foundation. The center is associated with the University of Bonn and offers a stimulating research environment through its international network, workshops and conferences, data service, project support, research visits and doctoral program. IZA engages in (i) original and internationally competitive research in all fields of labor economics, (ii) development of policy concepts, and (iii) dissemination of research results and concepts to the interested public.
\end{abstract}

IZA Discussion Papers often represent preliminary work and are circulated to encourage discussion. Citation of such a paper should account for its provisional character. A revised version may be available directly from the author. 


\section{ABSTRACT}

\section{A Bitter Medicine? Short-term Employment Impact of Deregulation in Network Industries ${ }^{*}$}

There is evidence that pro-competitive reforms in an industry with large incumbents induce the latter to re-organise and reduce prices in an attempt to deter entry of new competitors. Using data for three broadly-defined network industries in 23 OECD countries and covering over 30 years, I show that such re-organization has sizable negative short-term effects on industry employment. The employment losses, which last at least 3 years, are larger when reforms are implemented during downturns and insignificant when they take place in upturns. These findings contrast with previous evidence that deregulation in retail distribution has no (or even positive) short-term employment effects. This discrepancy is likely driven by the much larger employment share of small incumbents, with no margins of efficiency improvement, in retail than in network industries (as well as many other industries). Evidence on the immediate effect of removing entry barriers on industry prices and productivity is consistent with the hypothesis that the initial contraction of industry employment is the result of incumbents re-organising and downsizing before the entry of new competitors.

JEL Classification: J23, L11

Keywords: barriers to entry, structural reforms, job destruction, short-term costs, optimal timing of reforms

Corresponding author:

Andrea Bassanini

OECD

2 rue André Pascal

75775 Paris Cedex 16

France

E-mail: andrea.bassanini@oecd.org

\footnotetext{
* I am grateful to Luc Behaghel, Eve Caroli, Federico Cingano and Dominique Meurs for comments. I also thankfully acknowledge financial support from CEPREMAP, which however was not involved in any of the following research stages: study design; collection, analysis and interpretation of data; and writing of the paper. The opinions expressed in this paper are those of the author and cannot be attributed to the OECD or its Member Countries.
} 


\section{Introduction}

There is a wide consensus that many efficiency-enhancing structural reforms in the labour and product markets can improve economic performance in the long-run. ${ }^{1}$ However, the benefits of most of these reforms materialise gradually through hiring, firm entry and productivity growth, all processes that takes time. By contrast, negative effects in terms of job and income losses are likely to be immediate. As a result, the costs of structural reforms could overcome their benefits in the short-run. Measuring the balance between short-term costs and benefits of reforms is key to understand political opposition to their enforcement. It is also important in order to inform policy-makers about the optimal timing of implementation of these reforms and, even, their overall desirability. For example, reforms inducing large job destruction in the short-run might be less desirable during recessions, when these reforms may maximise job displacement and employment gains may take even longer lags due to lack of demand.

Available evidence suggests that liberalising entry induces quick price reductions and productivity growth as new, more efficient firms enter the market while incumbents reorganise by cutting costs and striving to achieve greater efficiency (e.g. Olley and Pakes, 1996; Schmitz, 2005). ${ }^{2}$ Incumbents' re-organisation is often accompanied by downsizing, but a few papers, focusing on liberalisation of entry in the retail industry, suggest that this is more than offset by job creation by entrants, with no overall short-term employment contraction in the industries affected by the reform (e.g. Bertrand and Kramarz, 2002). However, the retail sector is an industry characterised - before its liberalisation - by small, inefficient incumbents with limited margins of efficiency improvement. A few of these incumbents are driven out of the market in the aftermath of the reform, but this occurs only as a result of entry of more efficient competitors, which expand rapidly. By contrast, in other industries where large incumbents are the dominant players, it has been shown that the latter tend to react to the threat of entry by reducing prices and increasing efficiency even before new competitors enter the market (e.g. Goolsbee and Syverson, 2008; Bridgman et al., 2011; Brueckner et al., 2013). This suggests that the initial impact of pro-competitive reforms on industry-level employment could be negative since, in an attempt to deter entry or soften

\footnotetext{
${ }^{1}$ See for example Olley and Pakes (1996); Bertola (1999); Nickell and Layard (1999); Blanchard and Giavazzi, (2003); Boeri, (2011); Felbermayr and Prat (2011); and Syverson (2011) among many others.

${ }^{2}$ See also Boeri et al. (2015) for a recent survey.
} 
subsequent competition, large incumbents might re-organise and downsize well before new firms enter and start hiring.

In this paper, I examine the short-term effect of lowering barriers to entry on industry employment in three network industries (public utilities, transport and communications) that, in contrast with retail trade, are typically characterised by large incumbents, which are likely to immediately engage in re-organisation and reduction of overstaffing after deregulation of entry barriers. Using long time series of cross-country industry data I show that entry liberalisation has non-negligible short-term negative effects on employment in these industries, which vanish no earlier than 4 years after the reform. The effect is larger when reforms are implemented during downturns than in recoveries. I also show some evidence that deregulation immediately lowers price deflators and enhances productivity, which confirms that the initial employment contraction of deregulation is likely due to the fact that incumbents engage in entry-deterrence by re-organising and downsizing before the entry of new competitors.

I combine cross-country comparable employment data from the EUKLEMS and OECD STAN databases - two large databases reporting harmonised industry-level data mostly derived from national accounts - and measures of entry barriers in network industries from the OECD Product Market Regulation Database. ${ }^{3}$ The final dataset covers 3 industries and 23 countries, spanning over more than 30 years. With these data, I estimate the link between changes in regulation between two successive years and annual changes in industry employment using a variety of empirical models including simple first differences and more extensive dynamic models. I also derive impulse-response functions of the reaction of employment changes to changes in regulation using local-projection estimators as suggested by Jordà (2005) and Teulings and Zubanov (2014).

Using cross-country/cross-industry/time-series data for several countries, it is possible to estimate the association between annual changes in barriers to entry and annual changes in industry-specific employment levels by simultaneously controlling for all aggregate effects that are plausibly common to all industries of the same country, including most other structural reforms. In addition, I can take simultaneously into account industry-specific trends

\footnotetext{
${ }^{3}$ The latter includes a number of indicators that have been designed to pick up regulatory reforms in traditionally heavily regulated sectors and have been intensively used in academic research (e.g. Alesina et al., 2005; Felbermayr and Prat, 2011; Bassanini and Brunello, 2011; Fiori et al., 2012; Azmat et al., 2012; AparicioFenoll, 2015).
} 
as well as technology or demand shocks that are likely to be common across countries. Despite this, product market reforms remain endogenous and, therefore, estimated effects might still be biased. For example, industry-specific liberalisation reforms might be postponed (or undertaken more easily) when the industry faces a significant and persistent crisis. In that case, the analysis could attribute employment changes to liberalisation reforms when, in fact, the link is rather from industry-specific employment contraction to industryspecific deregulation. I tackle this issue in three ways. First, as I dispose of long time series, I estimate models with forward values of changes in regulation as an additional explanatory variable. If past or persistent employment changes were triggering changes in regulation, one should find a significant effect of forward regulatory indicators. However, forward terms turn out insignificant. Second, I test for reverse-causality through standard Granger-causality tests, which show no evidence that employment changes Granger-cause deregulation. These two exercises suggest that, conditional on the set of included controls, my estimates are not significantly affected by reverse causality. ${ }^{4}$ Another potential source of endogeneity are omitted confounding factors that could simultaneously cause industry deregulation and employment changes. In order to tackle this issue I need an instrument for deregulation. The political colour of local governments has been used as an instrument in earlier studies on the retail sector (e.g. Bertrand and Kramarz, 2002). Adapting this idea and exploiting the multicountry setting, I use a range of instruments related to the political colour of the national government, the size of its parliamentary majority, the newness of the government and whether it is composed by technocrats, drawing from the Comparative Political Data Set (Armingeon et al. 2014). Since all these variables are defined at the national level, however, the use of these instruments implies replacing, in the estimated IV models, country-by-time effects with a vector of aggregate co-variates.

This paper contributes to the literature on the labour market consequences of product market reforms. A general consensus in the theoretical literature suggests that product market reforms, by reducing rents and increasing firm entry, have a positive effect on employment in the long-run. ${ }^{5}$ The short-run employment effect is potentially ambiguous, as it crucially depends on the speed of job creation by entrants. ${ }^{6}$ A vast empirical literature also confirms that pro-competitive deregulation in the product markets has generally a positive effect on

\footnotetext{
${ }^{4}$ More precisely this statement holds for the specifications in which the deregulation indicator is lagged.

${ }^{5}$ See e.g. Blanchard and Giavazzi (2003); Ebell and Haefke (2009); Fang and Rogerson (2011); and Felbermayr and Prat (2011).

${ }^{6}$ As well as, at the macro-level, the short-run effect of deregulation on aggregate demand (e.g. Cacciatore et al., 2012).
} 
employment in the long-run (e.g. Peoples, 1998; Alesina et al., 2005; Griffith et al., 2007; Fiori et al., 2012). ${ }^{7}$ Reductions of entry barriers have been shown to induce a shift of jobs from incumbents to entrants, as the former strive to survive in the market by, among other measures, reducing overstaffing (e.g. Card, 1986; Viviano, 2008). Evidence from the retail sector tend to suggest that product market deregulation - be it of barriers to entry or of other aspects of business activities (such as shopping-time regulations) - induces short-term job losses by incumbents that are more than compensated by job creation by entrants with no or positive net employment gains (Bertrand and Kramarz, 2002; Viviano, 2008; Skuterud, 2005; Burda and Weil, 2005). This paper contributes to this literature by showing that this evidence cannot be generalised - and, in particular, do not generalise to utilities, transport and communications. This is likely because, as discussed above, in concentrated industries, large incumbents re-organise (and often downsize) before the entry of new competitors, in an effort to soften competition or deter entry. This suggests that reforms lowering barriers to entry are potentially costly in the short-run, and more research is needed to study the short-term impact in other industries.

The findings of this paper can also feed into the more general debate on the short-term effects of structural reforms and whether reforms that are beneficial in the long-run might involve short-term costs (see e.g. Cacciatore et al., 2012, for a recent theoretical contribution; and Boeri et al., 2015, for a recent survey revisiting the literature on labour and product market reforms with the aim of distinguishing between short and long-term consequences). This paper provides a clear example of reforms that might entail a more rapid effect on separations than on hiring, thereby resulting in employment losses soon after their implementation.

Another strand of literature this paper relates to is the investigation of the optimal timing of structural reforms with respect to the business cycle. In fact, the possibility that certain reforms might entail short-term costs brings about the question of whether they can be implemented during a recession or should be postponed to better times. Recently, several papers have addressed the issue of optimal labour market policy over the business cycle from both theoretical and empirical viewpoints (e.g. Landais et al., 2010; Mitman and Rabinovitch, 2011; Bouis et al., 2012; Kroft and Notowidigdo, 2014; Card et al., 2015; Jung and Kuester, 2015) but I am unaware of any such study as regards product market reforms. This paper

\footnotetext{
${ }^{7}$ The long-run effect of reducing barriers to entry has also been studied on other labour market dimensions such as wage rents (e.g. Black and Strahan, 2001); skill premia (e.g. Guadalupe, 2007); on-the-job training (e.g. Bassanini and Brunello, 2011); or job security (e.g. Aparicio-Fenoll, 2015).
} 
contributes to filling this gap by showing some evidence suggesting that liberalisation of barriers to entry yields the largest short-term employment cost when they are implemented in downturns, at least in certain industries.

The remainder of the paper is divided as follows: the next section sets forth the empirical methodology; Section 3 discusses the data and descriptive statistics; Section 4 presents the results; and a few concluding remarks are made in Section 5.

\section{Identification strategy and empirical specification}

The objective of this paper is to estimate the short-run employment effect of deregulation reforms. A simple way to investigate this relationship is to estimate a first-difference equation such that:

$$
\Delta E_{c j t}=\beta_{0} \Delta B E_{c j t}+X_{c j t} \gamma+D_{c t}+D_{j t}+D_{c j}+\varepsilon_{c j t}
$$

where $\Delta E$ stands for the annual change in the logarithm of employment in country $c$, industry $j$ and time $t, \triangle B E$ is the change in the regulation of entry barriers, $X$ is a vector of confounding factors that vary by country, industry and year, $\varepsilon$ stands for a standard error term $^{8}$ and the $D$ s represent all possible bi-dimensional fixed-effects capturing, in particular, changes in determinants of employment that are likely to affect in a similar way all industries (including the business cycle and other policy reforms), industry-specific non-linear trends that are common across countries (such as those related to the evolution of technology and global demand) as well as industry-specific linear trends in the evolution of industry employment that are different across countries.

In principle equation (2.1) would allow us to estimate the immediate effect of changes in regulation on changes in employment, de facto using industries and countries that do not deregulate in one specific year as a control for those that deregulated in that year. A positive coefficient of $\beta_{0}$ suggests that deregulation is associated with a negative immediate employment effect in affected industries. ${ }^{9}$ However, any omitted factor driving both changes

\footnotetext{
${ }^{8}$ As serial correlation may still be present in the residual, I systematically cluster standard errors at the countryby-industry level in all specifications estimated in this paper.

${ }^{9}$ In principle, entry-deterrence and competition-softening by incumbents implies a prediction for the sign of this coefficient only in the case of deregulation, with no clear prediction in cases of re-regulation. However, the latter are very rare in the data (see the next section), making insignificant any test statistics of parameter heterogeneity between deregulation and re-regulation episodes. Nonetheless, I check that my findings are robust if the few re-regulation episodes are excluded from the sample.
} 
in employment and changes in regulation is likely to bias OLS estimates. For example, industry-specific liberalisation reforms might be more easily undertaken when the industry faces a significant crisis. Alternatively, deregulation might be less resisted by trade unions when industry employment is on the rise so that organisational changes following deregulation are less likely to threaten the jobs of insiders. It is typically safer, therefore, to look at the effect of lagged values of the variable of interest ( $\triangle B E$ in our case) - and in particular of one-year-lagged values, since the objective is to estimate its short-run impact. This implies estimating:

$$
\Delta E_{c j t}=\beta_{1} \Delta B E_{c j t-1}+X_{c j t} \gamma+D_{c t}+D_{j t}+D_{c j}+\varepsilon_{c j t}
$$

with $\beta_{1}$ being the main parameter of interest, representing the estimated impact of changes in employment one year after the changes in regulation. Equation (2.2), however, does not take into account possible persistence in changes of employment (and - although less likely regulation). In order to take this into account, I also estimate a dynamic version of (2.2), that is:

$$
\Delta E_{c j t}=\sum_{k=1}^{T}\left(\beta_{k} \Delta B E_{c j t-k}+\delta_{k} \Delta E_{c j t-k}\right)+X_{c j t} \gamma+D_{c t}+D_{j t}+D_{c j}+\varepsilon_{c j t},
$$

with the number of lags defined on the basis of some statistical criterion such as the Bayesian's (BIC) or Akaike's (AIC). As noticed by Teulings and Zubanov (2014), however, estimating equation (2.3) could lead to biased coefficients because of the omission of systematic shocks that are simultaneous to the dependent variable - and in particular shocks to the variable of interest $\triangle \mathrm{BE}$. This suggests a slight modification of eq. (2.3):

$$
\begin{array}{r}
\Delta E_{c j t}=\beta_{0} \Delta B E_{c j t}+\sum_{k=1}^{T}\left(\beta_{k} \Delta B E_{c j t-k}+\delta_{k} \Delta E_{c j t-k}\right)+ \\
X_{c j t} \gamma+D_{c t}+D_{j t}+D_{c j}+\varepsilon_{c j t}
\end{array}
$$

without interpreting the estimate of $\beta_{0}$. As shown by Nickell (1981), the coefficients of the lagged dependent variable in equations (2.3) and (2.4) are usually biased. Equation (2.4) can be rewritten, however, by substituting recursively all terms of the lagged dependent variable, leading to an infinite series of $\triangle B E$ terms on the right-hand side (see e.g. Teulings and Zubanov, 2014). Since we are not interested in the coefficients of the lagged dependent variable, I can therefore estimate:

$$
\Delta E_{c j t}=\sum_{k=0}^{\mathfrak{T}} \beta_{k} \Delta B E_{c j t-k}+X_{c j t} \gamma+D_{c t}+D_{j t}+D_{c j}+\varepsilon_{c j t},
$$

with again $\mathfrak{I}$ set on the basis of BIC or AIC statistics (which would usually lead to $\mathfrak{I}>T$ ). 
Policy-makers might, however, react to negative employment shocks with some delay. If this is the case, one could attribute the association between changes in employment and lagged changes in regulation to a causal impact of the latter when, in fact, the relationship runs the other way. I test for this reverse-causality bias in two ways. First, I include forward terms in eq. (2.3)-(2.5): significant estimated coefficients of these terms would provide evidence of reverse causality. Second, I perform formal Granger-causality tests of changes in employment on changes in regulation, which essentially corresponds to inverting $\triangle B E$ and $\Delta E$ in eq. (2.3)-(2.4) and testing that $\Delta E$ terms have no individual or cumulative impact on $\triangle B E$.

An alternative strategy to take endogeneity concerns into account consists in adopting an instrumental-variable approach, which requires finding exogenous variables that are correlated with $\triangle B E$ but not with the residual of equation (2.1) and that can therefore be used as an instrument. ${ }^{10}$ As discussed in the introduction, following the previous literature, I rely on political variables characterising the political colour, strength and newness of the government as instruments. The idea is that reforms are more often undertaken by right-wing or technocratic governments with large parliamentarian support as soon as they take office. By contrast, political governments succeeding technocratic (and often unpopular) ones are perhaps more likely to have campaigned on a populist political platform, thereby being less likely to deregulate further once elected, no matter their political colour. ${ }^{11}$ However, since available political variables do not have an industry dimension, I cannot include country-bytime dummies in the specification. I therefore replace those dummies with aggregate changes in the output gap and either unemployment or aggregate employment (in order to control for aggregate influences on changes in employment) as well as a set of institutional variables that are normally included in cross-country/time-series employment regressions and that are also potentially affected by the set of instruments that I use. ${ }^{12}$ This implies estimating by twostage least squares (2SLS) the following specification:

$$
\Delta E_{c j t}=\beta_{0} \Delta B E_{c j t}+X_{c j t} \gamma+Y_{c t} \alpha+D_{j t}+D_{c j}+\varepsilon_{c j t}
$$

\footnotetext{
${ }^{10}$ In order to avoid inflating the number of instruments required for identification, I limit myself to run IV estimates of equation (2.1).

${ }^{11}$ The choice of instruments (among all possible political variables) is also guided by their significance in the first-stage regressions.

${ }^{12}$ I also check the consistency of my instrumental-variable strategy through standard over-identification tests.
} 
where $Y$ stands for a vector of aggregate confounding factors. One can still worry that downturns might simultaneously lead to changes in employment and in the political colour of governments. However, since the dynamics of aggregate employment is controlled for, $\Delta E$ should be seen as the relative variation of employment in sector $j$ with respect to the rest of the economy. As a consequence, the likelihood that the idiosyncratic evolution of employment in one industry leads to a change in cabinet composition is greater the greater share of aggregate employment that this industry represents. While transport and storage is relatively large (representing on average $6.7 \%$ of business-sector employment - excluding agriculture and mining - in the sample), the other two industries (post and communication and utilities) are very small (with an average share of non-agricultural/non-mining businesssector employment of $2.5 \%$ and $1.2 \%$, respectively), thereby making it very unlikely that idiosyncratic shocks to these industries affect national election results. As a robustness check, therefore, I re-run IV regressions excluding transport and storage.

As discussed in the introduction, a short-term negative impact of deregulation on employment has potential implications for the optimal timing of this type of structural reforms. In order to explore whether the impact of changes in regulation vary over the business cycle, I simply interact the change in regulation with the change in the output gap, computed at the aggregate level. A negative sign on this interaction would suggest that the immediate impact of deregulation on employment levels is more negative when economic activity is contracting while it is less so during recoveries.

Finally, if a negative immediate employment impact of deregulation is established, a key question from a policy perspective is how long it takes to absorb this negative effect. In order to explore this issue I complement my analysis by estimating the impulse-response function using the local-projection estimator developed by Teulings and Zubanov (2014). ${ }^{13}$ In practice, for the cumulated response after $\tau$ periods $C R(\tau)$, this implies estimating simultaneously, for each $h \leq \tau$, the $h$-period-ahead forecast as follows:

$$
\begin{array}{r}
\Delta E_{c j t+h}=\sum_{k=1}^{h} \beta_{k h} \Delta B E_{c j t+k}+\sum_{s=0}^{T} \beta_{s h} \Delta B E_{c j t-k}+\sum_{s=1}^{T} \delta_{k s} \Delta E_{c j t-s} \\
+D_{c t}+D_{j t}+D_{c j}+\varepsilon_{c j t}
\end{array}
$$

\footnotetext{
13 The advantage of local-projection estimators with respect to standard vector autoregressive (VAR) recursive estimation techniques is that they are more robust to misspecification, in particular at longer lags.
} 
and then derive $C R(\tau)=\sum_{h=1}^{\tau} \beta_{0 h}$. We are then interested in finding the minimum value of $\tau$ for which $C R(\tau)$ is insignificantly different from $0 .{ }^{14}$

\section{The data}

I use two main sources of data. The first one is the EUKLEMS database, which contains cross-country comparable industry-level data for a large number of OECD countries up to 2007. This dataset includes industry-level employment, hours worked, value-added, intermediate inputs, output and relative deflators at a level of disaggregation comprised between 1 and 2 digits of the ISIC rev. 3 classification. In particular, from this dataset, I can draw data for three network industries (utilities, transport and storage, and communications) that are typically heavily regulated.

The second data source is the OECD Regulation Database, which contains annual detailed indicators of anti-competitive product market regulation in seven 2 or 3 digit nonmanufacturing industries since 1975 (electricity, gas, road freight, railways, air transport, post and telecommunications). These indicators refer in particular to sector-specific entry barriers, vertical integration and public ownership. ${ }^{15}$ Available indicators vary between 0 and 6 from the least to the most regulated. Entry barriers cover legal limitations on the number of companies and rules on vertical integration of network industries. For example, in the case of the electricity industry, the indicator of industry-specific barriers to entry is the simple average of three sub-indicators concerning third-party access (free, regulated, no access), existence of a wholesale pool, and minimum consumption threshold that consumers must exceed in order to be able to choose their electricity supplier. A value of 0 corresponds to free entry. By contrast, a value of 6 applies when entry is severely restricted. Public ownership measures the share of equity owned by central or municipal governments, and takes a value of 0 in the case of no equity and a value of 6 in the case of full ownership.

\footnotetext{
${ }^{14}$ The estimator developed by Teulings and Zubanov (2014) improves upon the original one developed by Jordà (2005), by including simultaneous shocks as controls. Nonetheless, as a robustness check, I also estimate the impulse-response function on the basis of the latter, which is equivalent to deriving $C R(\tau)$ in the same way as above but without including the first term on the right-hand side of eq. (2.6).

${ }^{15}$ Other sector-specific indicators are available for certain industries such as the market share of the dominant player(s) (in the telephone, gas and railroad industries) and price controls (in the road freight industry). Outside the scope of this paper are also nation-wide aspects of regulations applying to all industries, such as administrative barriers to entrepreneurship (administrative barriers on start-ups, general features of the licensing and permit system, etc...), since these data are not available in time-series in the OECD database.
} 
Following Alesina et al. (2005) I obtain indicators of barriers to entry (including legal rules on vertical integration) and public ownership for the three aggregate industries (utilities, transport, and communication services), for which I have employment data, by simply averaging the values of the corresponding sub-industries. I then match these data with EUKLEMS data on industry-level employment and other variables and obtain a dataset covering 3 industries and 23 countries $^{16}$ from 1975 to 2007. As shown in Figure 1, all countries underwent a significant process of deregulation of barriers to entry during this period, ${ }^{17}$ although the timing of the deregulation differs across countries and industries, which - as discussed - provides our key source of identification. I then take the first difference of all the variables in the dataset in order to regress changes in employment on changes in regulation and other controls. The final, main dataset contains 1,891 observations. Means and standard deviation of all variables are reported in Table A1 in the Appendix. Changes in regulation are obviously 0 for the majority of observations, reflecting the discrete nature of reforms. Moreover, and not surprising, large reforms are relatively rare, a change in regulation of -0.92 or smaller being observed only in $5 \%$ of the observations.

In order to cover, as an extension, also the recent, great recession, I extend the sample to 2012 by merging EUKLEMS and OECD STAN, which also contain cross-country industrylevel employment data, although for a shorter time period and with industries disaggregated according to the ISIC rev.4 classification. The three industries considered here are not much affected by the change in the ISIC classification. Moreover, for each country/industry couple there is always at least one year for which employment is not missing in both databases. I therefore construct changes in log employment within each database and then replace missing values in EUKLEMS with employment changes from OECD STAN. To the extent that I use only changes - in both employment and regulation - in my analysis, minor breaks in the levels of employment in the two datasets are likely to bring about only minor errors in my estimations. Nevertheless, results from this extension must be taken with some caution.

As discussed in the previous section, I use four aggregate political variables as instruments, all derived from the 2012 edition of the Comparative Political Dataset (Armingeon et al.,

\footnotetext{
${ }^{16}$ Australia, Austria, Belgium, Canada, Czech Republic, Denmark, Finland, France, Germany, Greece, Hungary, Ireland, Italy, Japan, Korea, the Netherlands, Poland, Portugal, Slovakia, Spain, Sweden, the United Kingdom and the United States.

${ }^{17}$ There are also a few episodes of re-regulation, as shown by the few positive changes in the indicator (about $7 \%$ of all episodes of change in the indicator). However, these changes are essentially minor (always well below one standard deviation of the whole distribution, computed including also all observations with no change in regulation).
} 
2012): extent of right-wing government support, defined as the parliamentary seat share of right-wing (and centre) parties in government (weighted by the number of days in office in a given year); a dummy for change in the ideological composition of the government in that year, where the latter is measured through the Schmidt-index of cabinet composition; ${ }^{18}$ and two dummies denoting start and end of a technocratic government.

Finally, in a number of specifications I include additional aggregate variables. These are included either in specifications where country-by ${ }^{19}$-industry dummies are excluded (such as IV regressions) or in interaction with regulatory variables (in order to explore how the effect of deregulation changes over the business-cycle). In particular, I consider changes in the output gap, the logarithm of non-agricultural/non-mining business-sector employment and the logarithm of the harmonised unemployment rate (ILO definition) as well as changes in a number of labour market institutions that are typically included in aggregate regressions explaining labour-market performance (see e.g. Nickell et al., 2005; Bassanini and Duval, 2009). These include employment protection for regular contracts, trade union density, the level of coordination of collective bargaining, average gross replacement rates and the average tax wedge. All these variables are drawn from OECD databases except for the level of coordination that is drawn from the ICTWSS database (Visser, 2013) and business-sector employment that comes from EUKLEMS. Descriptive statistics of these variables are also reported in Table A1 in the Appendix.

\section{Results}

\subsection{The short-term employment impact of deregulation of entry barriers}

As a first step, I estimate the simultaneous association of year-on-year changes in regulation and in log employment (see eq. 2.1). The estimated coefficient suggests that, controlling for aggregate effects and industry-specific trends, a decrease in the indicator of stringency of barriers to entry of 1 point - a large reform in historical perspective since a change of such magnitude or more is observed in only about $5 \%$ of the sample, see the previous section - is

\footnotetext{
${ }^{18}$ The Schmidt index takes five values: 1 in the case of hegemony of right-wing (and centre) parties, 2 for dominance of right-wing (and centre) parties, 3 in the case of balance of power between left and right, 4 for dominance of social-democratic and other left parties, and 5 in the case of hegemony of social-democratic and other left parties. The dummy used in this article takes value 1 every time the Schmidt index changes value and 0 otherwise.

${ }^{19}$ The business sector - excluding mining and agriculture - corresponds to industry codes 15 to 74 in the ISIC rev.3 classification.
} 
associated with a decrease in employment of $0.6 \%$ (Table 1 , col. 1 ), ${ }^{20}$ which is twice as large as large as the average annual growth in employment in the sample. Lagging one year the regulatory variable yields similar results: a decrease in the indicator of stringency of barriers to entry is associated, one year later, with a decrease in employment of $0.7 \%$ (Table 1, col. 2). These findings are essentially unaltered if more dynamic models (cf. eq. 2.3-2.5) are estimated (Table 1, cols. 3-5), with the structure of lags defined by minimising the BIC statistic (see Table A2 in the Appendix for BIC and AIC statistics). ${ }^{21}$ Similar results are obtained by including additional controls for changes in public ownership, which turn out always insignificant (see Table A3 in the Appendix). ${ }^{22}$

As discussed in the previous section, these estimated coefficients might be biased because of reverse causality if policy makers react to changes in industry employment by speeding up or slowing down reforms in that industry. This concern applies also to the estimated elasticity of industry employment to lagged changes in regulation, if the reaction of lobbies or policy makers is not immediate. The direction of the bias is not obvious either. In fact, while it might be easier to reform an industry that is undergoing a period of crisis, at the same industry-specific lobbies could put pressure to postpone costly reforms when the industry is already downsizing. In order to address these issues, I re-estimate the models of Table 1 by additionally including one forward term - that is the change in regulation in the following year. If policy-makers reacted with some delay to employment changes, we would expect this term to be significant and the estimated coefficients of changes in regulation substantially altered. However, none of these possible outcomes occurs (Table 2). Interestingly, the coefficient of changes in regulation one year ahead is negative, although insignificant, suggesting that, if any, reforms tend to be undertaken, with some delay, when employment is growing.

\footnotetext{
${ }^{20}$ Table 1 is composed of 2 panels. Panel A is based on the limited sample including only more homogeneous EUKLEMS employment data (1975-2007). Panel B shows results obtained from the largest sample including also OECD STAN data (1975-2012).

${ }^{21}$ Each line of Table A2 presents AIC and BIC statistics for couples of models (with $T$ and $T-1$ lags) estimated on the same sample. The reason is that AIC and BIC statistics tend to decrease with the number of observations and, since I use all possible observations, the higher the number of lags and the smaller the sample. If the comparison is not performed on models estimated on the same sample (that is the largest sample for which I can estimate the model with $T$ lags) the criteria would always, but meaninglessly, lean in favour of the model with fewer lags.

${ }^{22}$ As a robustness check, in order to capture simultaneous shocks which could affect employment and therefore be confounding factors, I also include, alternatively, the real growth of intermediate inputs and value-added. Estimates of the parameters of interested (current and one-year-lagged effects of deregulation) are essentially unchanged (see Table A4 in the Appendix). I also check whether there is significant industry heterogeneity by allowing for industry-specific regulation coefficients, which turn out nonetheless insignificantly different across the three industries (results available from the author upon request).
} 
A more formal test of the same hypothesis is presented in Table 3 where Granger-causality tests of a possible impact of changes in employment on changes in regulation are performed for the dynamic models whose results are presented in Columns 3 and 4 of Table 1. Consistent with the results of Table 2, no evidence of reverse causality emerges from these tests: the first and second lags of employment changes do not appear to have a significant impact on the change in regulation (neither separately nor cumulatively).

An alternative approach to address endogeneity concerns is to use instrumental variables. I use four aggregate political variables as instruments: extent of right-wing government support, change in the ideological composition of the government; and two dummies denoting start and end of a technocratic government. As discussed in the previous sections their choice is partially guided by a priori reasoning - e.g. new, conservative or technocratic governments with large but homogeneous parliamentary support are possibly more likely to undertake costly reforms - but first and foremost by their empirical relevance in accounting for the endogenous variable in the first stage. ${ }^{23}$ As these variables relate to the nation-wide political situation - and hence are not industry-specific - I need to exclude country-by-time dummies in these specifications and have to rely on a set of aggregate variables (such as changes in the log unemployment rate $^{24}$, lagged changes in the output gap ${ }^{25}$ and a set of variables capturing changes in labour and other product market institutions) to proxy aggregate effects. The validity of the instruments is then evaluated through standard weakidentification and overidentification tests, which show no evidence of instrument weakness in particular after dropping insignificant covariates ${ }^{26}$ - or instrument endogeneity (Table 4, Panel A). ${ }^{27}$ The estimated effect of changes in barriers to entry appears significant at the $10 \%$ level and 3 times larger than OLS estimates (col 1). These results are unaffected by the

\footnotetext{
${ }^{23}$ It is important to note here that, for the identification strategy to be valid, the chosen instruments must only represent a relevant and independent source of variation. In other words, we need them to be exogenous and perform well in the first stage. There is no need, however, that the first stage includes all possible determinants of product market reforms, if the latter are not correlated with the political variables conditional on other controls (see e.g. Angrist and Pischke, 2009).

${ }^{24}$ Specifications including changes in the unemployment rate - instead of changes in log business-sector employment - are presented here because they yield a slightly better first-stage F statistic. Nonetheless, in a robustness exercise, I replicate the analysis by replacing changes in the log unemployment rate with changes in $\log$ employment in the business sector with identical results (available from the author upon request).

${ }^{25}$ There is evidence that fluctuations in aggregate employment typically follow those in GDP with some lag (e.g. OECD, 2012). For this reason, using one-year lagged output gaps in these specifications appears more appropriate.

${ }^{26}$ In Columns 2 and 3 of Panel A in Table 4 the F-statistic is above 10, thereby passing Stock and Staiger's rule of thumb (Staiger and Stock, 1997).

${ }^{27}$ Nevertheless, since the power of overidentification tests is limited and it is not possible to write and control for an exhaustive list of reforms that could be affected by the chosen political variables, the results from this exercise should be regarded with some caution.
} 
exclusion of either insignificant covariates (col 2) or of all institutional variables (col 3). This could suggest that reforms relaxing barriers to entry are easier and more frequently undertaken when industry employment is growing, thereby biasing towards the origin the coefficient when the latter is estimated by OLS. However, IV estimates do not appear very precise and standard exogeneity tests cannot reject the null of exogeneity of the change in entry barriers conditional on the co-variates, which suggests that OLS estimates can be consider as conservative lower bounds to the true effect.

As discussed in the previous sections, however, one could be concerned that employment fluctuations in large industries could affect the outcome of elections over and above aggregate employment fluctuations. For this reason, as a robustness check, I replicate the analysis by excluding transport and storage (Table 4, Panel B), which is the only industry in my dataset that accounts for more than $2.5 \%$ of non-agricultural/non-mining business-sector employment on average. Reassuringly, estimates of the parameter of interest appear unaffected. By contrast, in this case, instruments appear weaker.

\subsection{Heterogeneous effects over the business-cycle}

The results of the previous subsection suggest that, in network industries, deregulation of barriers to entry yields an increase in job destruction that initially exceeds any increase in job creation, thereby resulting in a net short-term contraction of employment. How does this effect vary over the business cycle? Is this negative effect magnified in recessions, when firms tend to shy away from new, uncertain activities while jobs are massively destroyed? Or conversely, are recoveries the best time for reforming entry barriers in these industries? To shed light on this issue, I augment the specifications of Table 1 with an interaction between changes in entry barriers and changes in the output gap measured at the time of the change in regulation. ${ }^{28}$ If deregulation takes place in recessions, this variable takes a positive value, while it takes a negative value when reforms are undertaken in booms (when the output gap is growing).

Table 5, Panel A, shows the result of this exercise for the main sample. While the estimated coefficient of the current interaction term is close to 0 and insignificant, the lagged

\footnotetext{
${ }^{28}$ As the change in the output gap is an aggregate variable, its linear effect is controlled for by country-by-time dummies. This implies that there is no need to include this variable as a linear term in the specification in order to interpret the coefficient of its interaction with the change in barriers to entry. Note also that, when the interaction is included, the coefficient of $\Delta$ Barriers to entry represents the effect of the latter when the change in the output gap is zero.
} 
interaction term attracts always a negative and significant term, which suggests that within two years from a deregulation reform, employment drops more when reforms are implemented while the economy is slowing down than when they are enforced during recoveries and booms. Interestingly, taking estimates at face value, the one-year-lagged effect of deregulation becomes insignificant (at the 10\% level) if the change in the output gap is positive and greater than 0.2 percentage points, which approximately corresponds to the median of the sample. Similar findings emerge when the extended sample (1975-2012) is used. In that case, however, the current interaction term attracts a negative, albeit insignificant, coefficient, while the estimated coefficient of the lagged interaction term is smaller. Yet, the sum of the two coefficients remain negative and significant, with a point estimate close to the one obtained on the smaller sample. ${ }^{29}$

Overall, these findings suggest that the short-term employment costs of liberalisation reforms are stronger in bad times, as job destruction brought about by incumbents' re-organisation tends to be larger in recessions. However, this does not necessarily imply that reforms are easier in good times, since in bad times it might be less difficult to build up a coalition supporting the reforms. Nonetheless, exploring this issue is beyond the scope of this paper.

\subsection{Impulse-response functions}

How long does it take for the initial negative employment effect of deregulation to be reverted? To answer this question, I estimate impulse response functions using localprojection estimators either à la Teulings and Zubanov or à la Jordà (see Section 2 for a discussion). In practice, this exercise implies fitting simultaneously eq. (2.6) for several values of $h$ in order to derive point estimates and standard errors for the cumulated response at different lags. The results of this exercise are presented in Figure 2. Independently of the method used, the cumulated impact on industry employment remains significant for the first three lags. By contrast, at lag 4, the cumulated impact is somewhat below the initial effect and insignificantly different from zero. Note, however, that the estimates become much less precise at lag 4 .

\footnotetext{
${ }^{29}$ Since, by and large, the extended sample differs from the main one only for the inclusion of the great recession of 2008-2009 and the subsequent timid recovery, a natural conjecture is that the negative short-term employment effect of deregulation reforms materialise particularly rapidly if reforms are undertaken during very bad downturns. Unfortunately, available data are not suited to explore further this conjecture.
} 
Taking these results at face value, it can be concluded that, on average, it takes at least 4 years after a liberalisation reform of barriers to entry to revert the initial negative effect on employment. It is important to note, in addition, that this result is conservative, since any simultaneous effect of changes in barriers to entry on changes in employment is not taken into account.

\subsection{Exploring the mechanism: barriers to entry, prices and productivity.}

As discussed in the introduction, the most convincing explanation for a negative short-term employment effect of deregulation of barriers to entry is that, while new firms take time to enter the market and expand their employment, incumbents rapidly re-organise and downsize with the aim of reducing slacks and lowering prices. If this is the case, one would expect that the reduction in barriers to entry is immediately reflected in a reduction in prices and an increase in labour productivity. Although a full exploration of this channel is beyond the scope of this paper, in order to provide some support for this hypothesis, I re-estimate the simple specifications corresponding to the first two columns of Table 1 by replacing changes in employment with, alternatively, changes in output prices - measured by the logarithm of the output deflator - and changes in labour productivity - measured as the logarithm of real value added per hour.

The results of this exercise are presented in Table 6. A reduction in barriers to entry of 1 point $^{30}$ appears to be significantly associated with a simultaneous fall in prices by $0.6 \%$ and an increase in labour productivity by $1.7 \%$. The fall in prices and the increase in productivity continue the year after, even if it becomes statistically insignificant. Although this evidence is far from being definitive, it appears consistent with the idea that incumbent firms restructure immediately in the aftermath of liberalisation episodes in an effort to increase their competitiveness and deter as much as possible entry or soften competition after entry.

\section{Concluding remarks}

Using industry-level cross-country comparable data covering 23 countries and over 30 years, this paper examines the short-term effect of reforms lowering barriers to entry in three broadly-defined industries that are typically characterised by large incumbents. Many studies

\footnotetext{
${ }^{30}$ Remember that this is a large reform in historical perspective since a change of such a magnitude or more occurs only in $5 \%$ of the observations of the sample.
} 
in industrial organisation have shown that large incumbents react to deregulation by reducing prices and increasing efficiency even before new competitors enter the market, in an attempt to deter entry or soften competition. This suggests that, in industries characterised by large incumbents, the initial impact of pro-competitive reforms on industry-level employment could be negative, since re-organisation and downsizing might occur well before new firms enter the market and start hiring. This paper provides evidence that this is indeed the case and that the induced short-term employment contraction is significant from an economic point of view.

These results contrast with findings of previous studies on the retail sector, which tend to find a non-negative short-term effect of deregulation of entry barriers on net job creation in that industry. The retail sector, however, is an industry characterised - before liberalisation - by small incumbents with limited margins of efficiency improvement that cannot therefore anticipate the entry of large, more efficient retailers. A few of these incumbents are driven out of the market, thereby destroying jobs, only when the large retailers enter and create jobs. My results thus suggest that the findings on the retail sector cannot be generalised and deregulation of barriers to entry can indeed be costly in terms of job losses in the affected industries, at least in the first few years following the policy reform. An open empirical question remains whether these findings are specific to a few industries or generalise to most of the traditionally-regulated industries.

These findings point to short-term distributional costs, since employees in industries affected by liberalisation of entry barriers initially lose from the reform. However, these results do not necessarily imply that deregulation entails economy-wide, short-term employment losses. In fact, job destruction in the industries affected by these reforms is the result of incumbents curbing overstaffing in order to reduce prices. However, the price decline following liberalisation gives a competitive advantage to domestic firms in other industries that use as inputs the goods and services produced by the previously-regulated industry. This effect is likely to be more important the more exposed to international competition the downstream industry and the least tradable the products of the upstream industry. Indeed previous studies have shown that deregulation in an upstream industry leads to significant export growth in those downstream industries that use more intensively goods and services of that industry as input (see e.g. Barone and Cingano, 2011). How rapidly, however, this channel may lead to net job creation in downstream industries of sufficient magnitude to compensate employment 
losses in the upward industry where barriers to entry are lowered remains an empirical issue. As far as I know, this question has never been explored so far and represents a promising avenue for further research.

\section{References}

Alesina, A., Ardagna, S., Nicoletti, G. and Schiantarelli, F. (2005), "Regulation and Investment," Journal of the European Economic Association, 3, pp. 791-825.

Angrist, J., and J.S. Pischke (2009), Mostly Harmless Econometrics, Princeton: Princeton University Press.

Aparicio-Fenoll, A. (2015), The Effect of Product Market Competition on Job Security, Labour Economics, forthcoming

Armingeon, K., L. Knöpfel, D. Weisstanner and S. Engler (2014), Comparative Political Data Set I 1960-2012, Bern: Institute of Political Science, University of Berne.

Azmat, G., A. Manning and J. Van Reenen (2012), Privatization, Entry Regulation and the Decline of Labor's Share in GDP: A Cross-Country Analysis of the Network Industries, Economica, vol. 79, pp. 470-492.

Barone, G., and F. Cingano (2011), Service Regulation and Growth: Evidence from OECD Countries, Economic Journal, 121, 931-957.

Bassanini, A., and G. Brunello (2011), Barriers to Entry, Deregulation and Workplace Training, European Economic Review, 55(8), 1152-1176.

Bassanini, A., and R. Duval (2009), Unemployment, Institutions, and Reform Complementarities: ReAssessing the Aggregate Evidence for OECD Countries, Oxford Review of Economic Policy, 25(1), 40-59.

Bertola, G. (1999), "Microeconomic perspectives on aggregate labor markets", in O.Ashenfelter and D.Card (eds), Handbook of Labor Economics, Elsevier.

Bertrand, M. and Kramarz, F. (2002), "Does entry regulation hinder job creation? Evidence from the French retail industry", Quarterly Journal of Economics, 117(4), pp. 1369-1413.

Black, S.E., and P.E. Strahan (2001), The Division of Spoils: Rent-Sharing and Discrimination in a Regulated Industry, American Economic Review, 91(4), 814-831.

Blanchard O, and F. Giavazzi (2003), Macroeconomic effects of regulation and deregulation in goods and labor markets, Quarterly Journal of Economics, 118, 879-907.

Boeri, T. (2011), "Institutional Reforms and Dualism in European Labour Markets", in Ashenfelter, O. and Card, D. (eds.), Handbook of Labour Economics, Amsterdam: Elsevier, pp. 1173-1236.

Boeri, T., P. Cahuc and A. Zylberberg (2015), The cost of flexibility-enhancing structural reforms, mimeo.

Bouis, R., O. Causa, L. Demmou and R. Duval (2012), How quickly does structural reform pay off? An empirical analysis of the short-term effects of unemployment benefit reform, IZA Journal of Labor Policy, 1, art. 12.

Bridgman, B., V. Gomes and A. Teixeira (2011), "Threatening to Increase Productivity: Evidence from Brazil’s Oil Industry”, World Development, Vol. 39, No. 8, pp. 1372-1385.

Brueckner, J. K., D. Lee and E.S.Singer (2013), "Airline competition and domestic US airfares: A comprehensive reappraisal, Economics of Transportation, Vol. 2, Issue 1, pages 1-17. 
Burda, M. and Weil, P. (2005), "Blue Laws", Woking Paper, European Center for Advanced Research in Economics and Statistics (ECARES), Université Libre de Bruxelles.

Cacciatore, M. R. Duval, and G. Fiori (2012), "Short-term pain or gain? A DSGE model-based analysis of the short-term effects of structural reforms in labour and product markets", OECD Economics Department Working Papers, No.948.

Card, D. (1986), “The Impact of Deregulation on the Employment and Wages of Airline Mechanics", Industrial and Labor Relations Review, 39, 527-38

Card, D., A. Johnston, P. Leung, A. Mas and Z. Pei (2015), The Effect of Unemployment Benefits on the Duration of Unemployment Insurance Receipt: New Evidence from a Regression Kink Design in Missouri, 2003-2013, mimeo.

Ebell, M., and C. Haefke (2009), Product Market Deregulation and the U.S. Employment Mira-cle, Review of Economic Dynamics, 12(3), 479-504.

Fang, L., and R. Rogerson (2011), Product Market Regulation and Market Work: A Benchmark Analysis, American Economic Journal: Macroeconomics, 3(2), 163-88

Felbermayr, G. and J.Prat (2011), "Product Market Regulation, Firm Selection and Unemployment", Journal of the European Economic Association, 2011, Vol. 9(2), pp. 278-317

Fiori, G., G. Nicoletti, S. Scarpetta and F. Schiantarelli (2012), Employment Effects of Product and Labour Market Reforms: Are There Synergies?, Economic Journal, Vol. 122, Issue 558, pages F79F104

Goolsbee, A. and Syverson, C. (2008), "How do incumbents respond to the threat of entry? Evidence from the major airlines", Quarterly Journal of Economics, 123(4), pp. 1611- 1633.

Griffith, R., Harrison, R. and Macartney, G. (2007), "Product market reforms, labour market institutions and unemployment", Economic Journal, 117(519), pp. 142-166.

Guadalupe, M. (2007), Product Market Competition, Returns to Skill, and Wage Inequality, Journal of Labor Economics, 25, 439-474.

Jordà, O. (2005), Estimation and inference of impulse responses by local projections, American Economic Review, vol.95(1): 161-182.

Jung, P., and K. Kuester (2015), "Optimal Labor-Market Policy in Recessions", American Economic Journal: Macroeconomics, forthcoming.

Kroft, K., and M. J. Notowidigdo (2014), "Should Unemployment Insurance Vary with the Unemployment Rate? Theory and Evidence," mimeo.

Landais, C., P. Michaillat, and E. Saez (2010), “A Macroeconomic Theory of Optimal Unemployment Insurance", NBER Working Papers 16526.

Mitman, K., and S. Rabinovich (2011), "Pro-cyclical Unemployment Benefits? Optimal Policy in an Equilibrium Business Cycle Model." PIER Working Paper No 11-023.

Nickell, S. (1981), Biases in Dynamic Models with Fixed Effects, Econometrica, 49(6), 1417-1426.

Nickell, S. and R. Layard (1999), "Labor Market Institutions and Economic Performance", in O.Ashenfelter and D.Card (eds), Handbook of Labor Economics, Elsevier.

Nickell, S., L. Nunziata and W. Ochel (2005), "Unemployment in the OECD Since the 1960s: What Do We Know?”, Economic Journal, Vol. 115, No. 500, pp.1-27.

OECD (2012), Employment Outlook, Paris: OECD Publishing.

Olley, S. and Pakes, A. (1996), "The Dynamics of Productivity in the Telecommunications Equipment Industry", Econometrica, 64(6), pp. 263-297.

Peoples, J. (1998), Deregulation and the Labor Market, Journal of Economic Perspectives, 12(3), 111-130. 
Schmitz, J. (2005), "What Determines Productivity? Lessons from the Dramatic Recovery of the U.S. and Canadian Iron Ore Industries Following Their Early 1980s Crisis", Journal of Political Economy, 113(1), pp. 582-625.

Skuterud, M. (2005), "The impact of Sunday Shopping on Employment and Hours of Work in the Retail Industry: Evidence from Canada", European Economic Review, 49(8), pp. 1953-1978.

Staiger, D., and J.H. Stock (1997), Instrumental Variables Regression with Weak Instruments, Econometrica, 65(3), 557-583.

Syverson, C. (2011), "What Determines Productivity?", Journal of Economic Literature, 49(2), 326365 .

Teulings, C. and N. Zubanov (2014), "Is Economic Recovery a Myth? Robust Estimation of Impulse Responses”, Journal of Applied Econometrics, vol. 29, pp. 497-514.

Viviano, E. (2008), "Entry regulations and labour market outcomes: Evidence from the Italian retail trade sector," Labour Economics, vol. 15(6), pages 1200-1222.

Visser, J. (2013), ICTWSS: Database on Institutional Characteristics of Trade Unions, Wage Setting, State Intervention and Social Pacts in 34 Countries between 1960 and 2012, Version 4 - April 2013, http://www.uva-aias.net/208 . 
Figure 1: Evolution of the indicator of barriers to entry, by country and industry, 1975-2007
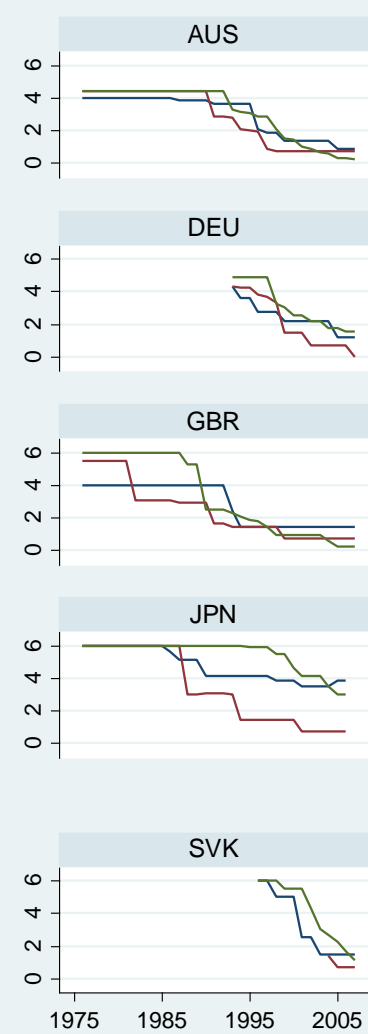
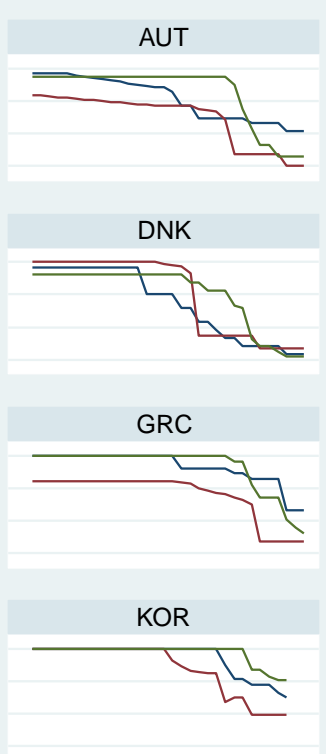

SWE

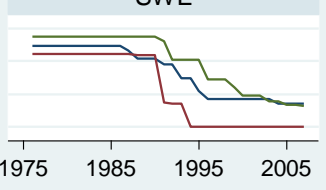

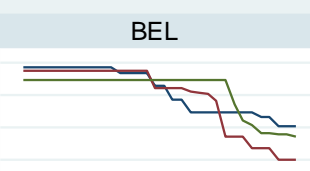

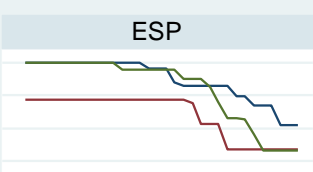

HUN
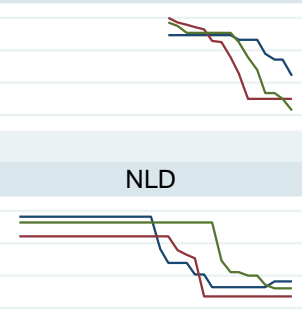

USA

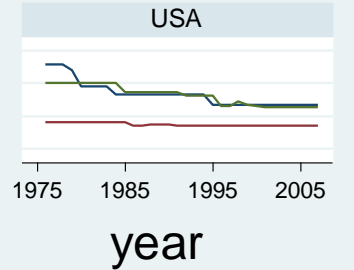

Transport

Energy
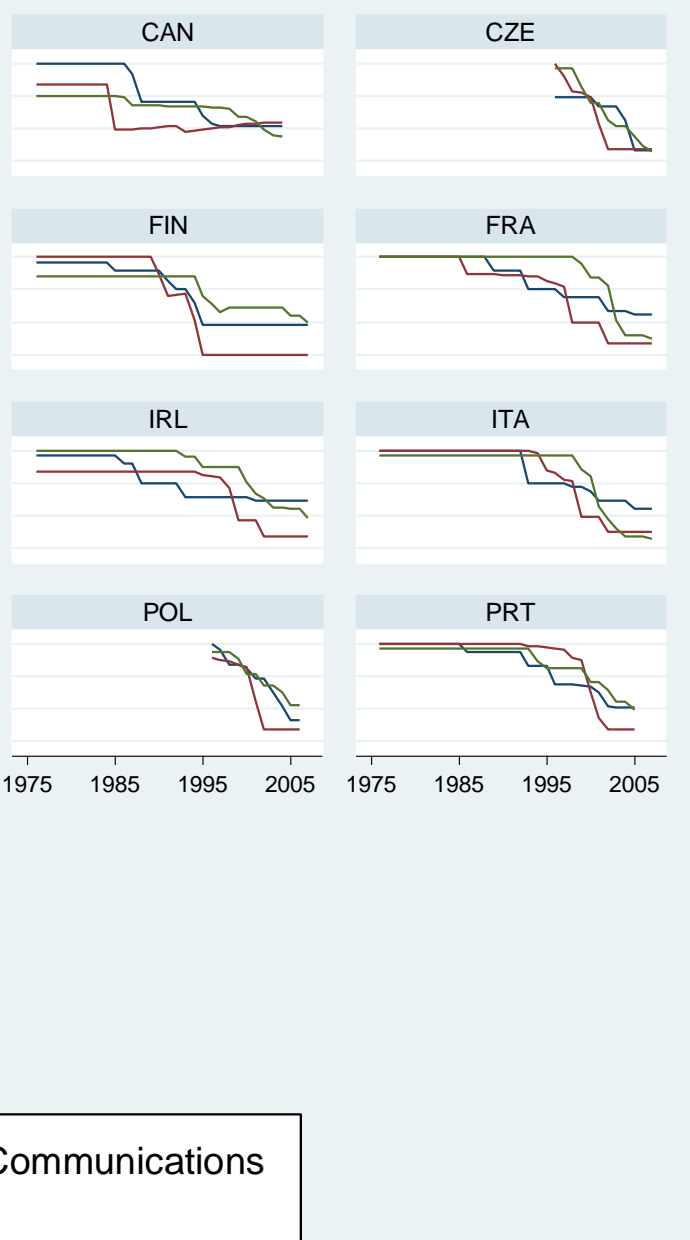

Notes: OECD Indicator of barriers to entry and vertical integration. Only data points for which industry employment is available are displayed. 


\section{Figure 2. Impulse-response functions}

Panel A: Teulings-Zubanov's local-projection estimator

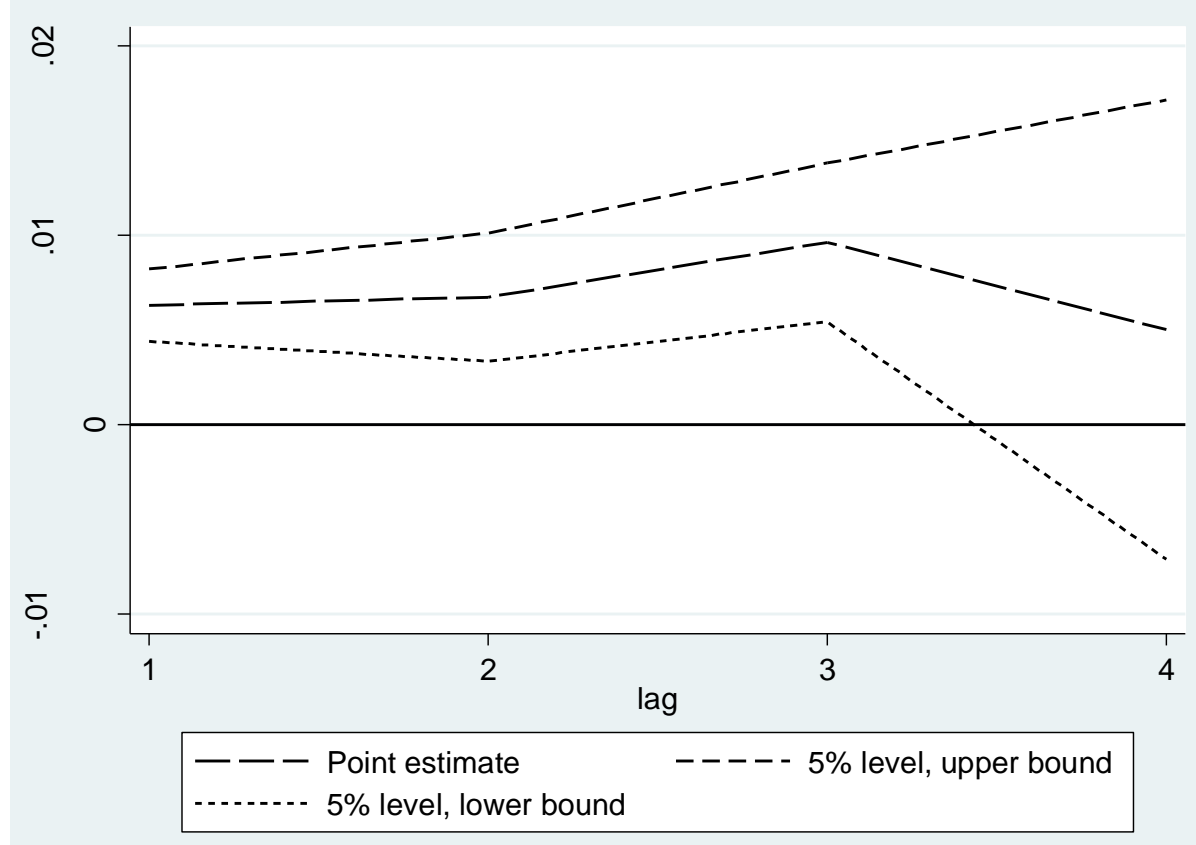

\section{Panel B: Jordà's local-projection estimator}

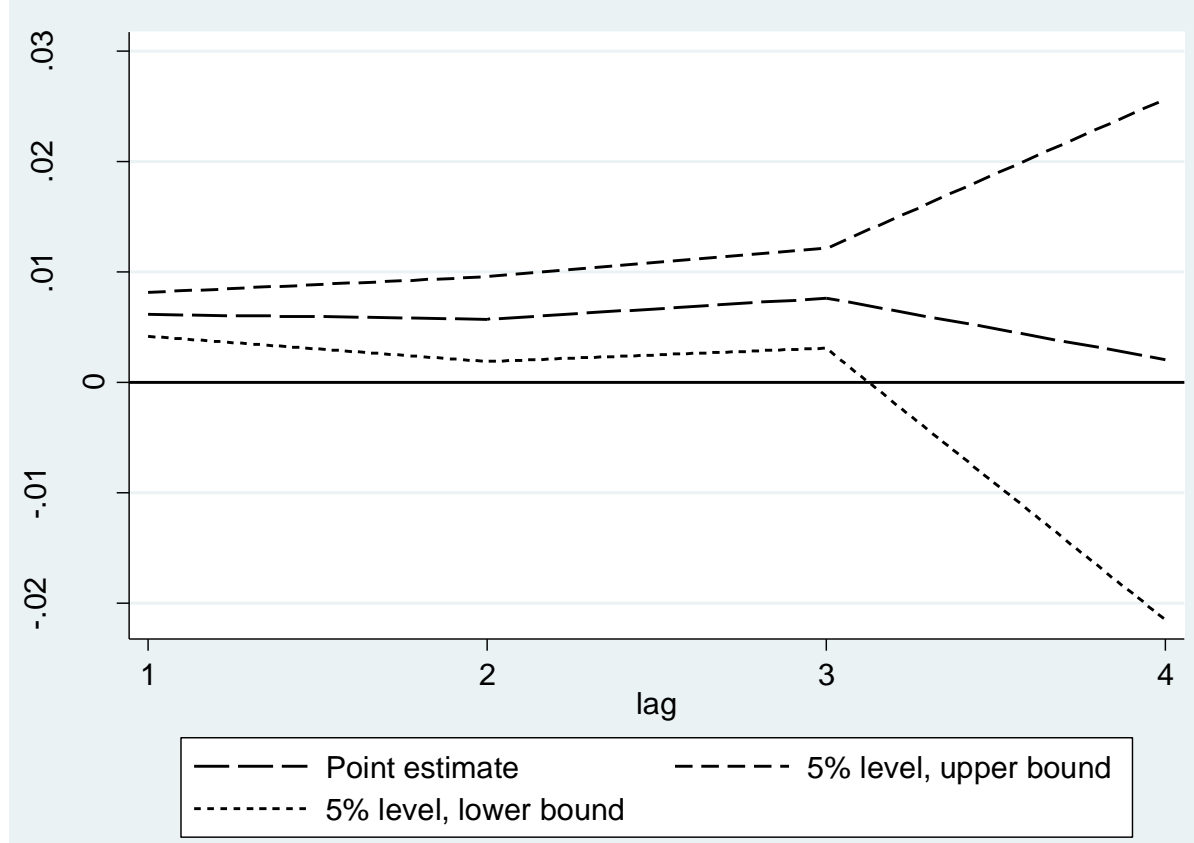

Notes: cumulated estimated effect of changes in barriers to entry on changes in employment after 1, 2, 3 and 4 lags. Bounds refer to 5\%-level confidence intervals. 
Table 1 Baseline results

Panel A: Main sample (1975-2007)

(1)

(2)

(3)

(4)

(5)

$\Delta$ Barriers to entry

$0.0059 *$

$0.0066 * * \quad 0.0069^{* *}$

(0.0030)

$(0.0032) \quad(0.0031)$

$\Delta$ Barriers to entry $(t-1)$

$0.0069 * *$

$0.0062 *$

$0.0072 * *$

$\Delta$ Barriers to entry $(t-2)$

$\left.\begin{array}{llll}(0.0033) & (0.0032) & (0.0032) & (0.0034\end{array}\right)$

$\begin{array}{lll}0.0001 & 0.0009 & 0.0005\end{array}$

$\begin{array}{lll}(0.0032) & (0.0033) & (0.0034)\end{array}$

$\Delta$ Barriers to entry $(t-3)$

0.0037

$(0.0032)$

$\Delta$ Barriers to entry $(t-4)$

$-0.0047$

$(0.0034)$

$\Delta$ Barriers to entry $(t-5)$

0.0068*

(0.0036)

$\Delta \log$ Employment $(t-1)$

$0.0161 \quad 0.0170$

(0.0456) (0.0454)

$\Delta \log$ Employment $(t-2)$

$-0.1416 * * \quad-0.1442 * *$

Country-industry dummies

$(0.0575) \quad(0.0566)$

Industry-time dummies

Yes

Yes

Yes

Yes

Country-time dummies

Yes

Yes

Yes

Yes

Yes

Observations

Yes

Yes

Yes

Yes

Yes

R-squared

0.556

0.555

1,753

1,753

1,547

R-squared 
Table 1 Baseline results (cont.)

Panel B: Extended sample (1975-2012)

(1)

(2)

$0.0062 * *$
$(0.0030)$

$\Delta$ Barriers to entry

(0.0030)

$\Delta$ Barriers to entry $(t-1)$

$\Delta$ Barriers to entry $(t-2)$

$\Delta$ Barriers to entry $(t-3)$

$\Delta$ Barriers to entry $(t-4)$

$\Delta$ Barriers to entry $(t-5)$

$\Delta \log$ Employment $(t-1)$

$\Delta \log$ Employment $(t-2)$
(3)

(4)

(5)

\begin{tabular}{cccc} 
& & $0.0067^{* *}$ & $0.0061^{* *}$ \\
$0.0061^{*}$ & $0.0056^{*}$ & $0.0057^{*}$ & $0.0067^{*}$ \\
$(0.0033)$ & $(0.0032)$ & $(0.0032)$ & $(0.0035)$ \\
& 0.0001 & 0.0009 & -0.0001 \\
& $(0.0031)$ & $(0.0031)$ & $(0.0032)$ \\
& & & 0.0040 \\
& & & $(0.0029)$ \\
& & & -0.0043 \\
& & & $(0.0029)$ \\
& & & $0.0059^{*}$ \\
& & & $(0.0034)$ \\
& $(0.0438$ & 0.0438 & \\
& $-0.1149 * *$ & $(0.0454)$ & \\
& $(0.0553)$ & $(0.0542)$ & \\
\hline Yes & Yes & Yes & Yes \\
Yes & Yes & Yes & Yes \\
Yes & Yes & Yes & Yes \\
\hline 2,051 & 1,962 & 1,962 & 1,827 \\
0.560 & 0.577 & 0.578 & 0.561 \\
\hline
\end{tabular}

Country-industry dummies

Industry-time dummies

Country-time dummies

Observations

0.560

0.577

0.578

0.561

Notes: Dependent variable: $\Delta$ log Employment. Standard errors, adjusted for clustering at the countryby-industry level, in parentheses. ${ }^{* * *} \mathrm{p}<0.01, * * \mathrm{p}<0.05,{ }^{*} \mathrm{p}<0.1$. 
Table 2 Including forward terms

(1)

$(2)$

(3)

(4)

(5)

\begin{tabular}{lccccc}
$\Delta$ Barriers to entry & $0.0059^{*}$ & & & $0.0065^{* *}$ & $0.0062^{*}$ \\
& $(0.0030)$ & & & $(0.0032)$ & $(0.0032)$ \\
$\Delta$ Barriers to entry $(t-1)$ & & $0.0063^{*}$ & $0.0053^{*}$ & $0.0055^{*}$ & $0.0068^{* *}$ \\
& & $(0.0033)$ & $(0.0032)$ & $(0.0031)$ & $(0.0034)$ \\
$\Delta$ Barriers to entry $(t+1)$ & -0.0018 & -0.0014 & -0.0015 & -0.0013 & -0.0008 \\
& $(0.0029)$ & $(0.0030)$ & $(0.0029)$ & $(0.0028)$ & $(0.0032)$ \\
\hline Country-industry dummies & Yes & Yes & Yes & Yes & Yes \\
Industry-time dummies & Yes & Yes & Yes & Yes & Yes \\
Country-time dummies & Yes & Yes & Yes & Yes & Yes \\
\hline Observations & 1,822 & 1,753 & 1,684 & 1,684 & 1,479 \\
R-squared & 0.559 & 0.558 & 0.574 & 0.576 & 0.562 \\
\hline N- & & &
\end{tabular}

Notes: Dependent variable: $\Delta \log$ Employment. Columns 3 and 4 include a second lag of $\Delta$ Barriers to entry and one and two lags of the dependent variable. 3 additional lags of $\Delta$ Barriers to entry are included in Column 5. Standard errors, adjusted for clustering at the country-by-industry level, in parentheses. $* * * \mathrm{p}<0.01, * * \mathrm{p}<0.05, * \mathrm{p}<0.1$.

Table 3 Granger-causality tests of reverse causality

\begin{tabular}{lcc}
\hline & $(1)$ & $(2)$ \\
\hline & Not including & Including \\
& $\Delta$ log Employment $(t)$ & $\Delta \log$ Employment $(t)$ \\
\hline F-test on $\Delta$ log Employment $(t-1)$ & 0.20 & 0.24 \\
F-test on $\Delta$ log Employment $(t-2)$ & 1.94 & 2.62 \\
F-test, cumulative impact & 0.38 & 0.64 \\
\hline
\end{tabular}

Notes: The table presents F-tests of the coefficients of the first two lags of $\Delta$ log Employment in models where $\Delta$ Barriers to entry is the dependent variable and two lags of both $\Delta$ Barriers to entry and $\Delta \log$ Employment (as well as country-by-industry, country-by-time and industry-by-time dummies) are included. "F-test, cumulative" stands for the F-test on the sum of both lagged $\Delta \log$ Employment coefficients. F-statistics are distributed as $\mathrm{F}(1,68)$ under the null (test statistics are obtained by clustering errors at the country-by-industry level). None of the reported statistics is significant at standard levels. 
Table 4 IV regressions

\section{Panel A: All industries}

(1) (2)

(3)

$\Delta$ Barriers to entry

$0.0240 * \quad 0.0253 * * \quad 0.0238 *$

$\Delta \log$ Unemployment rate

$\begin{array}{lll}(0.0129) & (0.0125) & (0.0126)\end{array}$

$-0.0447 * * * \quad-0.0442 * * * \quad-0.0418 * * *$

$\Delta$ Output gap $(t-1)$

$\begin{array}{lll}(0.0124) & (0.0136) & (0.0137)\end{array}$

$\begin{array}{lll}0.0015 & 0.0014 & 0.0017^{*}\end{array}$

$\Delta$ Tax wedge

$\begin{array}{lll}(0.0010) & (0.0010) \quad(0.0010)\end{array}$

$-0.0014 * * \quad-0.0015 * *$

(0.0006) (0.0006)

$\Delta$ Bargaining coordination

$0.0053 * * \quad 0.0054 * *$

$(0.0021) \quad(0.0021)$

$\Delta \mathrm{EPL}$

0.0022

(0.0119)

$\Delta$ Trade union density

0.0005

$(0.0014)$

$\Delta$ Average replacement rate

0.0004

(0.0005)

$\Delta$ Public ownership

0.0004

(0.0039)

\begin{tabular}{lccc}
\hline Country-industry dummies & Yes & Yes & Yes \\
Industry-time dummies & Yes & Yes & Yes \\
Country-time dummies & No & No & No \\
\hline First stage F statistic & 9.5 & 11.6 & 11.3 \\
Hansen J overidentification test (P-val.) & 0.29 & 0.33 & 0.30 \\
Robust score test of exogeneity (P-val.) & 0.24 & 0.22 & 0.25 \\
Robust regr.-based test of exogeneity (P-val.) & 0.26 & 0.23 & 0.27 \\
\hline Observations & 1,188 & 1,188 & 1,188 \\
\hline OLS Estimate of $\Delta$ Barriers to entry & $0.0072^{* *}$ & $0.0074^{* *}$ & $0.0071^{* *}$ \\
(same specification and sample) & $(0.0028)$ & $(0.0028)$ & $(0.0029)$ \\
\hline
\end{tabular}


Table 4 IV regressions (cont.)

Panel B: Utilities and communications

(1) (2)

(3)

$\Delta$ Barriers to entry

$0.0282 * \quad 0.0302 * \quad 0.0289 *$

$\Delta \log$ Unemployment rate

$\begin{array}{lll}(0.0161) & (0.0157) \quad(0.0157)\end{array}$

$-0.0372 * * \quad-0.0362 * * \quad-0.0340 *$

$\Delta$ Output gap $(t-1)$

$(0.0159) \quad(0.0176)$
$0.0010)$

(0.0176)

$0.0010 \quad 0.0009$

0.0011

$(0.0014) \quad(0.0014)$

(0.0014)

$\Delta$ Tax wedge

$-0.0011$

$-0.0011$

$(0.0009) \quad(0.0009)$

$\Delta$ Bargaining coordination

$0.0065 * * \quad 0.0067 * *$

$(0.0028) \quad(0.0028)$

$\Delta \mathrm{EPL}$

0.0032

$(0.0159)$

$\Delta$ Trade union density

0.0010

$(0.0019)$

$\Delta$ Average replacement rate

0.0008

(0.0006)

$\Delta$ Public ownership

0.0015

$(0.0050)$

\begin{tabular}{lccc}
\hline Country-industry dummies & Yes & Yes & Yes \\
Industry-time dummies & Yes & Yes & Yes \\
Country-time dummies & No & No & No \\
\hline First stage F statistic & 6.9 & 8.6 & 8.3 \\
Hansen J overidentification test (P-val.) & 0.53 & 0.59 & 0.58 \\
Robust score test of exogeneity (P-val.) & 0.22 & 0.19 & 0.21 \\
Robust regr.-based test of exogeneity (P-val.) & 0.24 & 0.21 & 0.23 \\
\hline Observations & 792 & 792 & 792 \\
\hline OLS Estimate of $\Delta$ Barriers to entry & $0.0078^{* *}$ & $0.0081^{* *}$ & $0.0078^{* *}$ \\
(same specification and sample) & $(0.0035)$ & $(0.0035)$ & $(0.0035)$ \\
\hline
\end{tabular}

Notes: 2SLS Estimates. Dependent variable: $\Delta$ log Employment. Panel B excludes Transport and storage. All covariates except $\Delta$ Barriers to entry are treated as exogenous. Extent of right-wing government support, change in the ideological composition of the government, and two dummies denoting start and end of technocratic governments are used as instruments for $\Delta$ Barriers to entry. First stage F statistic stands for the Kleibergen-Paap rk Wald F statistic. Only P-values are reported for overidentification and exogeneity tests (respectively Hansen J test and Wooldridge's robust score and regression based tests). For comparison, the last two lines of each panel report, in each column, the point estimate and standard error of the coefficient of the endogenous variable as obtained by OLS on the same sample and using the same specification, with $\Delta \log$ Employment as dependent variable, as for IV estimates reported in the same column. EPL: Employment Protection Legislation. Standard errors, adjusted for clustering at the country-by-industry level, in parentheses. $* * * \mathrm{p}<0.01, * * \mathrm{p}<0.05$, * $\mathrm{p}<0.1$. 
Table 5 Interactions with the cycle

Panel A: Main sample (1975-2007)

(1)

(2)

(3)

(4)

(5)

$\Delta$ Barriers to entry

$0.0071^{* *}$

(0.0029)

$0.0080 * * * 0.0088 * * *$

$\Delta$ Barriers to entry $(t-1)$

$\begin{array}{llll}0.0053^{*} & 0.0048^{*} & 0.0050^{*} & 0.0058^{* *}\end{array}$

$\Delta$ Barriers to entry $(t-2)$

$\left.\begin{array}{llll}(0.0028) & (0.0028) & (0.0028) & (0.0029\end{array}\right)$

$\begin{array}{lll}0.0023 & 0.0033 & 0.0029\end{array}$

$\begin{array}{lll}(0.0027) & (0.0027) & (0.0030)\end{array}$

$\Delta$ Barriers to entry $(t-3)$

0.0031

$(0.0035)$

$\Delta$ Barriers to entry $(t-4)$

$-0.0051 *$

$(0.0030)$

$\Delta$ Barriers to entry $(t-5)$

0.0046

(0.0035)

$\Delta$ Barriers to entry* $\Delta$ Output

$-0.0002$

0.0000

0.0004

gap

(0.0013)

$(0.0013) \quad(0.0012)$

$\Delta$ Barriers to entry $(t-1)^{*}$

$\Delta$ Output gap $(t-1)$

$\Delta$ Barriers to entry $(t-2)^{*}$

$\Delta$ Output gap $(t-2)$

$\begin{array}{llll}-0.0026 * * & -0.0029 * * & -0.0029 * * & -0.0023 *\end{array}$

$\begin{array}{lllll}(0.0012) & (0.0013) & (0.0013) & (0.0013)\end{array}$

$\begin{array}{lll}0.0016 & 0.0015 & 0.0018\end{array}$

$\begin{array}{lll}(0.0017) & (0.0017) \quad(0.0018)\end{array}$

$\Delta$ Barriers to entry $(t-3)^{*}$

$\Delta$ Output gap $(t-3)$

0.0016

$(0.0018)$

0.0020

$\Delta$ Barriers to entry $(t-4)^{*}$

$(0.0015)$

$\Delta$ Output gap $(t-4)$

0.0005

$\Delta$ Barriers to entry $(t-5)^{*}$

(0.0016)

$\Delta$ Output gap $(t-5)$

Country-industry dummies

Industry-time dummies

Yes

Yes

Yes

Yes

Country-time dummies

Observations

Yes

Yes

Yes

Yes

Yes

R-squared

Yes

Yes

1,750

1,684

Yes

Yes

0.570

0.570

0.583

1,618

1,421

0.589 
Table 5 Interactions with the cycle (cont.)

Panel B: Extended sample (1975-2012)

(1)

$\Delta$ Barriers to entry

$\Delta$ Barriers to entry $(t-1)$

$\Delta$ Barriers to entry $(t-2)$

$\Delta$ Barriers to entry $(t-3)$

$\Delta$ Barriers to entry $(t-4)$

$\Delta$ Barriers to entry $(t-5)$

$\Delta$ Barriers to entry* $\Delta$ Output gap

$\Delta$ Barriers to entry $(t-1)^{*}$ $\Delta$ Output gap $(t-1)$

$\Delta$ Barriers to entry $(t-2)^{*}$ $\Delta$ Output gap $(t-2)$

$\Delta$ Barriers to entry $(t-3)^{*}$ $\Delta$ Output gap $(t-3)$

$\Delta$ Barriers to entry $(t-4)^{*}$ $\Delta$ Output gap $(t-4)$

$\Delta$ Barriers to entry $(t-5)^{*}$ $\Delta$ Output gap $(t-5)$
$0.0074^{* *}$

$(0.0028)$

\begin{tabular}{|c|c|c|c|c|}
\hline $0.0074 * *$ & & & $0.0080^{* * *}$ & $0.0095 * * *$ \\
\hline 0028) & & & (0.0028) & $\begin{array}{l}(0.0028) \\
0.0049 *\end{array}$ \\
\hline & $\begin{array}{c}0.0045 \\
(0.0029)\end{array}$ & $\begin{array}{c}0.0043 \\
(0.0028)\end{array}$ & $\begin{array}{c}0.0044 \\
(0.0028)\end{array}$ & $\begin{array}{l}0.0049^{x} \\
(0.0029)\end{array}$ \\
\hline & & 0.0019 & 0.0029 & 0.0032 \\
\hline & & $(0.0027)$ & $(0.0027)$ & $(0.0030)$ \\
\hline & & & & 0.0042 \\
\hline & & & & $(0.0032)$ \\
\hline & & & & $-0.0047^{*}$ \\
\hline & & & & $(0.0025)$ \\
\hline & & & & 0.0049 \\
\hline & & & & $(0.0033)$ \\
\hline-0.0013 & & & -0.0006 & -0.0003 \\
\hline$(0.0012)$ & & & $(0.0012)$ & $(0.0012)$ \\
\hline & $-0.0023 *$ & $-0.0023^{*}$ & $-0.0024^{*}$ & -0.0015 \\
\hline & $(0.0012)$ & $(0.0012)$ & $(0.0012)$ & $(0.0013)$ \\
\hline & & $0.0028^{*}$ & 0.0026 & $0.0029 *$ \\
\hline & & $(0.0016)$ & $(0.0016)$ & $(0.0017)$ \\
\hline & & & & 0.0026 \\
\hline & & & & $(0.0018)$ \\
\hline & & & & $0.0025^{*}$ \\
\hline & & & & $(0.0014)$ \\
\hline & & & & -0.0001 \\
\hline & & & & $(0.0016)$ \\
\hline Yes & Yes & Yes & Yes & Yes \\
\hline Yes & Yes & Yes & Yes & Yes \\
\hline Yes & Yes & Yes & Yes & Yes \\
\hline 1,959 & 1,893 & 1,820 & 1,820 & 1,629 \\
\hline 0.576 & 0.576 & 0.591 & 0.594 & 0.594 \\
\hline
\end{tabular}

(3) (4) (5)

(2)

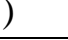

Notes: Dependent variable: $\Delta \log$ Employment. Columns 3 and 4 also include the first and second lags of the dependent variable. Standard errors, adjusted for clustering at the country-by-industry level, in parentheses. ${ }^{* * *} \mathrm{p}<0.01, * * \mathrm{p}<0.05, * \mathrm{p}<0.1$. 
Table 6 Prices and productivity

\begin{tabular}{lcccc}
\hline Dependent variable & $\begin{array}{c}(1) \\
\Delta \text { Output } \\
\text { deflator }\end{array}$ & $\begin{array}{c}\Delta \text { Output } \\
\text { deflator }\end{array}$ & $\begin{array}{c}\Delta \text { Labour } \\
\text { productivity }\end{array}$ & $\begin{array}{c}\Delta \text { Labour } \\
\text { productivity }\end{array}$ \\
\hline Barriers to entry & & & & \\
& $0.0062^{* *}$ & & $-0.0167^{* *}$ & \\
$\Delta$ Barriers to entry $(t-1)$ & $(0.0028)$ & & $(0.0083)$ & \\
& & 0.0025 & & -0.0082 \\
Country-industry dummies & Yes & Yes & Yes & Yes \\
Industry-time dummies & Yes & Yes & Yes & Yes \\
Country-time dummies & Yes & Yes & Yes & Yes \\
\hline Observations & 1,891 & 1,822 & 1,891 & 1,822 \\
R-squared & 0.803 & 0.803 & 0.498 & 0.495 \\
\hline
\end{tabular}

Notes: Standard errors, adjusted for clustering at the country-by-industry level, in parentheses. $* * *$ $\mathrm{p}<0.01, * * \mathrm{p}<0.05, * \mathrm{p}<0.1$. 
Table A1: Descriptive statistics

\section{Appendix}

Panel A: Main sample (1975-2007)

\begin{tabular}{lccc}
\hline & Obs. & Mean & Std.Dev. \\
\hline$\Delta$ log employment & 1891 & .0035 & .0426 \\
$\Delta$ barriers to entry (0-6 scale) & 1891 & -.1446 & .3906 \\
$\Delta$ log intermediate inputs (volume) & 1891 & .0517 & .0921 \\
$\Delta$ log value added (volume) & 1891 & .0409 & .0679 \\
$\Delta$ log output price deflator & 1891 & .0452 & .0698 \\
$\Delta$ log value-added deflator & 1891 & .0022 & .0041 \\
$\Delta$ log labour productivity & 1891 & .0386 & .0748 \\
$\Delta$ public ownership (0-6 scale) & 1891 & -.0696 & .2708 \\
$\Delta$ tax wedge (\%) & 1227 & -.046 & 1.795 \\
$\Delta$ average gross replacement rate (\%) & 1738 & .1758 & 1.601 \\
$\Delta$ trade union density (\%) & 1852 & -.5389 & 1.304 \\
$\Delta$ EPL, regular workers (0-6 scale) & 1480 & -.0084 & .074 \\
$\Delta$ bargaining coordination (1-5 scale) & 1798 & -.0172 & .6126 \\
$\Delta$ log harmonised unemployment rate & 1675 & .0033 & .1427 \\
$\Delta$ log business-sector employment & 1891 & .0097 & .0239 \\
$\Delta$ output gap (\%) & 1750 & .104 & 1.586 \\
Change in government ideology (0-1) & 1656 & .2138 & .4101 \\
Right-wing government support (\%) & 1656 & 21.48 & 23.09 \\
Start of technocratic government (0-1) & 1891 & .0032 & .0563 \\
End of technocratic government (0-1) & 1891 & .0032 & .0563 \\
\hline Panel B: Extended sample (1975-2012) & & & \\
\hline & & & \\
\hline$\Delta$ log employment & 2107 & .0021 & .0427 \\
$\Delta$ barriers to entry (0-6 scale) & 1959 & -.0386 & .3793 \\
$\Delta$ output gap (\%) & & & 1.84 \\
\hline$N$ Obs. & & Mean & Std.Dev. \\
\hline
\end{tabular}

Notes: EPL: Employment Protection Legislation 
Table A2 BIC and AIC statistics

Panel A: lagged dependent variables but no current change in regulation

\begin{tabular}{lcccc}
\hline & $\mathrm{BIC}(T)$ & $\mathrm{BIC}(T-1)$ & $\mathrm{AIC}(T)$ & $\mathrm{AIC}(T-1)$ \\
\hline 4 lags vs. 3 lags & -6568.652 & -6576.538 & -6902.651 & -6899.763 \\
3 lags vs. 2 lags & -6821.562 & -6832.222 & -7163.585 & -7163.387 \\
2 lags vs. 1 lag & -7111.362 & -7089.964 & -7455.914 & -7423.578 \\
\hline
\end{tabular}

Panel B: lagged dependent variables and current change in regulation

\begin{tabular}{lcccc}
\hline & $\mathrm{BIC}(T)$ & $\mathrm{BIC}(T-1)$ & $\mathrm{AIC}(T)$ & $\mathrm{AIC}(T-1)$ \\
\hline 4 lags vs. 3 lags & -6567.968 & -6577.041 & -6907.355 & -6905.653 \\
3 lags vs. 2 lags & -6821.79 & -6832.037 & -7169.241 & -7168.631 \\
2 lags vs. 1 lag & -7112.009 & -7089.251 & -7462.031 & -7428.334 \\
\hline
\end{tabular}

Panel C: no lagged dependent variables

\begin{tabular}{lcccc}
\hline & $\mathrm{BIC}(T)$ & $\mathrm{BIC}(T-1)$ & $\mathrm{AIC}(T)$ & $\mathrm{AIC}(T-1)$ \\
\hline 10 lags vs. 9 lags & -4865.502 & -4871.855 & -5135.584 & -5136.841 \\
9 lags vs. 8 lags & -5177.644 & -5182.824 & -5455.782 & -5455.812 \\
8 lags vs. 7 lags & -5483.27 & -5489.576 & -5769.417 & -5770.519 \\
7 lags vs. 6 lags & -5797.103 & -5804.281 & -6091.218 & -6093.144 \\
6 lags vs. 5 lags & -6087.739 & -6094.887 & -6389.789 & -6391.638 \\
5 lags vs. 4 lags & -6282.974 & -6282.747 & -6592.93 & -6587.359 \\
\hline
\end{tabular}

Notes: BIC: Bayesian Information Criterion. AIC: Akaike Information Criterion. The statistics used to select the number of lags in Column 3, 4 and 5 of Table 1 are presented in Panels A, B and C, respectively. 
Table A3 Baseline results, controlling for public ownership

\begin{tabular}{|c|c|c|c|c|c|}
\hline & $(1)$ & (2) & (3) & (4) & $(5)$ \\
\hline$\Delta$ Barriers to entry & $\begin{array}{c}0.0060 * * \\
(0.0030)\end{array}$ & & $\begin{array}{c}0.0067 * * \\
(0.0031)\end{array}$ & $\begin{array}{c}0.0067 * * \\
(0.0031)\end{array}$ & $\begin{array}{c}0.0067 * * \\
(0.0030)\end{array}$ \\
\hline$\Delta$ Barriers to entry $(t-1)$ & & $\begin{array}{l}0.0068^{*} \\
(0.0034)\end{array}$ & $\begin{array}{l}0.0062 * \\
(0.0032)\end{array}$ & $\begin{array}{l}0.0062 * \\
(0.0032)\end{array}$ & $\begin{array}{l}0.0065^{*} \\
(0.0033)\end{array}$ \\
\hline$\Delta$ Barriers to entry $(t-2)$ & & & $\begin{array}{c}0.0008 \\
(0.0034)\end{array}$ & $\begin{array}{c}0.0008 \\
(0.0034)\end{array}$ & $\begin{array}{l}-0.0002 \\
(0.0037)\end{array}$ \\
\hline$\Delta$ Barriers to entry $(t-3)$ & & & & & $\begin{array}{c}0.0034 \\
(0.0033)\end{array}$ \\
\hline$\Delta$ Barriers to entry $(t-4)$ & & & & & $\begin{array}{l}-0.0060 * \\
(0.0034)\end{array}$ \\
\hline$\Delta$ Barriers to entry $(t-5)$ & & & & & $\begin{array}{c}0.0069 * \\
(0.0037)\end{array}$ \\
\hline$\Delta$ Public ownership & $\begin{array}{l}-0.0022 \\
(0.0050)\end{array}$ & & $\begin{array}{l}-0.0026 \\
(0.0049)\end{array}$ & $\begin{array}{l}-0.0026 \\
(0.0049)\end{array}$ & $\begin{array}{c}-0.0048 \\
(0.0050)\end{array}$ \\
\hline$\Delta$ Public ownership $(t-1)$ & & $\begin{array}{c}0.0015 \\
(0.0052)\end{array}$ & $\begin{array}{c}0.0008 \\
(0.0050)\end{array}$ & $\begin{array}{c}0.0008 \\
(0.0050)\end{array}$ & $\begin{array}{c}0.0037 \\
(0.0058)\end{array}$ \\
\hline$\Delta$ Public ownership $(t-2)$ & & & $\begin{array}{c}0.0052 \\
(0.0051)\end{array}$ & $\begin{array}{c}0.0052 \\
(0.0051)\end{array}$ & $\begin{array}{c}0.0102 * * \\
(0.0046)\end{array}$ \\
\hline$\Delta$ Public ownership $(t-3)$ & & & & & $\begin{array}{c}-0.0027 \\
(0.0063)\end{array}$ \\
\hline$\Delta$ Public ownership $(t-4)$ & & & & & $\begin{array}{c}0.0059 \\
(0.0062)\end{array}$ \\
\hline$\Delta$ Public ownership $(t-5)$ & & & & & $\begin{array}{l}0.0097 * \\
(0.0057)\end{array}$ \\
\hline$\Delta \log$ Employment $(t-1)$ & & & $\begin{array}{c}0.0163 \\
(0.0458)\end{array}$ & $\begin{array}{c}0.0163 \\
(0.0458)\end{array}$ & \\
\hline$\Delta \log$ Employment $(t-2)$ & & & $\begin{array}{c}-0.1442 * * \\
(0.0560) \\
\end{array}$ & $\begin{array}{c}-0.1442 * * \\
(0.0560)\end{array}$ & \\
\hline Country-industry dummies & Yes & Yes & Yes & Yes & Yes \\
\hline Industry-time dummies & Yes & Yes & Yes & Yes & Yes \\
\hline Country-time dummies & Yes & Yes & Yes & Yes & Yes \\
\hline Observations & 1,891 & 1,822 & 1,753 & 1,753 & 1,547 \\
\hline R-squared & 0.556 & 0.555 & 0.575 & 0.575 & 0.568 \\
\hline
\end{tabular}

Notes: See Table 1 
Table A4 Baseline results, including controls for simultaneous shocks

Panel A: including intermediate inputs growth

(1) (2)

$\Delta$ Barriers to entry

$0.0064 * *$

$(0.0029)$

$\Delta$ Barriers to entry $(t-1)$

Observations

R-squared

Panel B: including real value added growth

\begin{tabular}{lccccc}
\hline & $(1)$ & $(2)$ & $(3)$ & $(4)$ & $(5)$ \\
\hline & & & & & \\
$\Delta$ Barriers to entry & $0.0063^{* *}$ & & & $0.0071^{* *}$ & $0.0069^{* *}$ \\
& $(0.0030)$ & & & $(0.0032)$ & $(0.0031)$ \\
$\Delta$ Barriers to entry $(t-1)$ & & $0.0069^{* *}$ & $0.0061^{*}$ & $0.0063^{*}$ & $0.0072^{* *}$ \\
& & $(0.0033)$ & $(0.0032)$ & $(0.0032)$ & $(0.0034)$ \\
\hline Observations & 1,891 & 1,822 & 1,753 & 1,753 & 1,547 \\
R-squared & 0.557 & 0.556 & 0.574 & 0.576 & 0.563 \\
\hline
\end{tabular}

Panel C: including both intermediate inputs and real value added growth

(1)

$0.0066^{* * *}$

(0.0029)

$\Delta$ Barriers to entry $(t-1)$

\begin{tabular}{lccccc}
$\Delta$ Barriers to entry & $0.0066^{* *}$ & & & $0.0075^{* *}$ & $0.0074^{* *}$ \\
& $(0.0029)$ & & & $(0.0031)$ & $(0.0030)$ \\
$\Delta$ Barriers to entry $(t-1)$ & & $0.0067^{* *}$ & $0.0060^{*}$ & $0.0062^{*}$ & $0.0072^{* *}$ \\
& & $(0.0033)$ & $(0.0032)$ & $(0.0032)$ & $(0.0034)$ \\
\hline Observations & 1,891 & 1,822 & 1,753 & 1,753 & 1,547 \\
R-squared & 0.561 & 0.559 & 0.576 & 0.579 & 0.567 \\
\hline
\end{tabular}

Notes: Dependent variable: $\Delta$ log Employment. All specifications include country-by-industry, countryby-time and industry-by-time dummies. All specifications in Panel A include the change in the logarithm of intermediate inputs, while all those in Panel B include the change in the logarithm of real value added. Both these sets of covariates are simultaneously included in Panel C. Columns 3 and 4 in all panels include a second lag of $\Delta$ Barriers to entry and one and two lags of the dependent variable. Column 5 includes 5 lags of $\Delta$ Barriers to entry. Standard errors, adjusted for clustering at the countryby-industry level, in parentheses. $* * * \mathrm{p}<0.01, * * \mathrm{p}<0.05, * \mathrm{p}<0.1$. 